\title{
Summary Jurisdiction in Bankruptcy Related to Possible Referee Disqualification
}

\author{
Martin Gendel*
}

$\mathrm{U}$ NTIL ABOUT ten years ago bankruptcy practitioners generally believed that when an alleged creditor filed a claim in a bankruptcy proceeding the bankruptcy court was einpowered merely to determine whether that particular claim would be allowed. ${ }^{1}$ The last decade has seen increased judicial and commentator support for the proposition that the filing creditor submits to the bankruptcy court's summary jurisdiction over issues involving the estate, even though such issues are not included in the proof of claim and even though the determination could result in an affirmative judgment against the claimant. On the other hand, Congress, some courts, a minority of legal writers and bankruptcy authorities, and certain creditor groups have not officially accepted this extension of jurisdiction, and some of them would deny or restrict the growing tendency. This article will analyze the probable reasons underlying resistance to the extension of summary jurisdiction.

Apparently the referee has unquestioned authority to allow the trustee ${ }^{2}$ to set-off estate claims against the creditor even though they are not involved in the creditor's proof of clain. Can the truslee affirmatively recover money or property froin the claimant? The majority rule is that, notwithstanding his timely objection, the creditor's filing of a proof of claim constitutes consent to jurisdiction, permitting the trustee to seek affirmative relief in regard to inatters arising froin the transaction involved in the original claim. ${ }^{3}$ There is some conflict of authority whether a trustee may obtain

* A.B., 1929, U.C.L.A.; LL.B., 1932, University of California School of Law, Berkeley; Member, California Bar; Lecturer in Law, School of Law, University of Southern California.

${ }_{1}$ See Gendel, Jurisdiction of a Referee in Bankruptcy to Render Affirmative Judgment on a Counterclaim in Favor of a Trustee, 26 So. CAL. L. REv. 167 (1953), reprinted in 27 REF. J. 90 (1953).

2 Hereinafter references to a "trustee" include the "receiver."

3 The courts of appeals of eight circuits are in apparent agreement that the filing of a proof of claim is implied consent or voluntary submission to the exercise of summary jurisdiction on matters related to the subject matter of the claim, thereby permitting affirmative relief for the trustee. Powell v. Maher, 307 F.2d 397 (D.C. Cir.), cert. denied, 371 U.S. 910 (1962) ; Nortex Trading Corp. v. Newfield, 311 F.2d 163 (2d Cir. 1962); Commercial Discount Co. v. Rutledge, 297 F.2d 370 (10th Cir. 1961); Peter v. Lines, 275 F.2d 919 (9th Cir. 1960) ; Continental Cas. Co. v. White, 269 F.2d 213 (4th Cir. 1959); In re Majestic Radio and Television Corp., 227 F.2d 152 (7th Cir. 1955), cert. denied, 350 U.S. 995 (1956); Floro Realty \& Inv. Co. v. Steem Elec. Corp., 128 F.2d 338 (8th Cir. 1942).

In the 5th Circuit, the court's holding in B.F. Avery \& Sons Co. v. Davis, 192 F.2d 255 (5th Cir. 1951), cert. denied, 342 U.S. 945 (1952), that a proof of claim is not consent to sum- 
an affirmative judgment on a cause of action arising from a transaction not involved in the original claim. ${ }^{4}$ Some courts have held that if a creditor files a proof of secured claim or an application for reclamation, he may expressly provide that the filing shall not constitute a consent to jurisdiction beyond the claim or application. ${ }^{5}$

Proponents of affirmative jurisdiction in the bankruptcy courts argue that the trial of all issues in a single proceeding desirably avoids a multiplicity of actions. "'It makes it unnecessary to split the trustee's counterclaim and eliminates the need for offensive action by the trustees in another court with respect to the excess. Obviously the determination of all issues by the bankruptcy court tends to expedite the administration of the bankrupt estate and carries out the Congressional purpose of ... the [Bank-

mary jurisdiction with respect to matters unrelated to the claim may be viewed as impliedly adopting the above rule.

While the 6th Circuit has not ruled on the question, at least two district courts within the circuit are in accord with the above rule. See $I n$ re Scott-Frederick Motor Co., 177 F. Supp. 758 (E.D. Ky. 1959) ; In te Morrison-Barnhart Motors, 142 F. Supp. 845 (N.D. Ohio 1956).

In addition to the arguments based upon imphed consent or voluntary submission to summary jurisdiction, a theory bas been employed that the claimant is in a position analogous to that of a plaintiff in an ordinary federal civil action and as such he is exposed to the operative effect of the counterclaim rule of Federal Rule of Civil Procedure 13. In Nortex Trading Corp. v. Newfield, supra, the court relied on both theories. And in United States v. Verrier, $179 \mathrm{~F}$. Supp. 336 (D. Me. 1959), where the Rule 13 analogy was not carried to its logical conclusion, it was held that the trustee's failure to assert what amounted to a compulsory counterclaim under Rule 13 (a) did not bar the undischarged bankrupt from seeking recovery on the claim. The court cited In re Majestic Radio and Television Corp., supra, and noted that General Order 37 applies where a conflict between Federal Rules of Civil Procedure and the Bankruptcy Act arises. In other words, abandonment of a burdensome claim by the trustee is not to operate as a nullification of the claim in the hands of the bankrupt.

For an extensive discussion of the principal problems, see generally 2 CoLIIER, BANXRUPTCX \$ 23.08 [5], [6] (14th ed. 1962); 5 REMTINGTON, BANKRUPTCX \$\$2200-02 (Supp. 1962); Nadler, Summary Jurisdiction to Render Affirmative Judgment on Counterclaims, Set-offs and Reclamations, 29 RER. J. 39 (1955) ; Seligson \& King, Jttrisdiction and Venue in Bankruptcy, 36 REF. J. 73 (1962); Treister, Summary Jurisdiction, 36 CAIrF. S.B.J. 1085, 1089-90 (1961); 44 CoRneli L.Q. 107, 114-16 (1958); 60 Mich. L. Rev. 96 (1961), reprinted in 36 REF. J. 114 (1962); 39 TEXas L. REv. 674 (1961).

4 Compare Inter-State Nat'l. Bank v. Luther, $221 \mathrm{~F} .2 \mathrm{~d} 382$ (10th Cir. 1955), cert. granted, 350 U.S. 810, cert. dismissed, 350 U.S. 944 (1956) with In re Majestic Radio and Television Corp., supra note 3 ; In re C. A. Goldsmith Co., 122 F. Supp. 19 (D.N.J. 1954).

Some courts apparently avoid the same transaction-different transaction dichotomy by viewing the facts as being part of the same transaction, when arguably they are not . See, e.g., Continental Cas. Co. v. White, 269 F.2d 213 (4th Cir. 1959); In re Farrell Publishing Corp., 130 F. Supp. 449 (S.D.N.Y. 1955).

${ }^{5}$ See In re Eakin, 154 F.2d 717 (2d Cir. 1946); Glens Falls Ins. Co. v. Strom, 198 F. Supp. 450 (S.D. Cal. 1961); In re Industrial Associates, Inc., 155 F. Supp. 866 (E.D. Pa. 1957). Cf. Pickens v. Roy, 187 U.S. 177 (1902). See generally 2 Colime, BankruptCY $\$ 23.08$, at 555-56, nn.79-81 (14th ed. 1962).

${ }^{6}$ See Seligson \& King, supra note 3 at 73. 
ruptcy Act]." On the other hand, it has been argued that the effect of affirmative jurisdiction may be to keep creditors out of the bankruptcy courts. ${ }^{8}$ A creditor may desire to defend agamst the possible claim of a trustee in a plenary proceeding $\mathrm{m}$ the state or district court, rather than submit to the summary jurisdiction of a referee.

To mitigate this problem it has been proposed that the Bankruptcy Act be amended to require the creditor to expressly consent to all counterclaims. ${ }^{9}$ If the creditor does not consent, his claim would be disallowed. The trustee's claim could then be litigated in a plenary suit at the option of the trustee with a possible counterclaim by the creditor. The proponent of this solution points out that "both causes of action would still be determimed in one suit and multiplicity of actions would be avoided." 10

Assuming that avoidance of a multiplicity of actions is desirable, proceeding before the referee in a bankruptcy court would certainly be more practical than requiring the trustee to file a plenary action in a state or federal court. There is additional delay and expense in bringing a separate action in a state or federal court. Also, a referee is governed by the same Federal Rules of Civil Procedure that govern the district courts; litigants may no longer complain that they are being subjected to a kangaroo court. Furthermore, encouraging such actions in state or federal courts disregards Congress's expressed desire in creating a bankruptcy court. Congress established the bankruptcy court and the referee system to assist the district courts in the administration of the Bankruptcy Act. Judges do not have the time either to be administrators of estates or to handle the complicated problems of a bankruptcy proceeding.

Another possible objection to the extended jurisdiction of the bankruptcy court is that the referee may be unduly influenced by information received outside the formal bankruptcy hearing. To consider this problem one must be aware of the facts of life as they exist in a bankruptcy court. The referee not only acts as a judicial officer but also supervises a inyriad of administrative and business details conducted by receivers, trustees, adjusters, auctioneers, accountants, debtors in possession, and attorneys. One of the original reasons for creating the position of referee in the bankruptcy court was to relieve the district judge of these many duties and details. In a sense, a referee wears two hats: he is a true judicial officer, and he supervises the liquidation or perpetuation of assets and businesses as a quasi-administrative officer.

In his administrative role a referee is exposed to many matters con-

TId. at 83.

8 Comment, 39 Texas L. Rev. 674 (1961).

9 Id. at 676.

10 Ibid. 
cerning the estate. Both the provisions of the Bankruptcy Act and practical requirements for protection of the rights of all creditors and for equitable distribution of available dividends encourage exploratory examinations in the bankruptcy court concerning the assets, liabilities, acts, and conduct of the bankrupt or debtor. Discovery hearings take place before a referee from the time a bankruptcy proceeding is filed. These hearings often commence with an informal conference in chambers during which the referee is enlightened in regard to the problems of the estate, and where frequently a receiver is appointed. When presenting administrative matters to the referee, receivers (and subsequently trustees) and their representatives are inclined to yield to the frailties of human nature and discuss problems arising im the administration of a bankruptcy court proceeding. Although there may be no intent to influence the referee, such a result may follow unbeknown to the creditor, who perhaps has not yet even filed his claim.

Thus, a referee acting in good faith, but subject to the mechanics of bankruptcy administration, may be exposed to statements concerning the very issues to be decided by him in a subsequent bankruptcy court proceeding. Taking the benign approach that the referee is qualified to disregard what he has already heard is tantamount to expecting that the jury in a personal injury action will blot out a statement by a witness or counsel that the defendant is insured after being admonished to do so by the judge. ${ }^{11}$ What protection can be given to the claimant who finds himself exposed to serious affirmative claims by the trustee, and finds that the very witnesses who will be needed in this proceeding have already been examined by the trustee or his counsel before the referee concerning some of the same facts involved in the pending proceeding for affirmative relief?

One form of possible relief is available to the creditor through judicial disqualification. As the Banlsruptcy Act now stands, sections $22(\mathrm{~b})^{12}$ and $39(\mathrm{~b})^{13}$ are the only sections covering disqualification of a referee. Section 39 (b) deals solely with situations involving conflicting interests of a referee, ${ }^{14}$ and section 22 (b) merely states that: "The judge may, at any

11 See Briggs v. Superior Court, 215 Cal. 336, 344 (1932), in which the court stated: "It is our opinion that in this case the state of mind of the challenged judge must be determined by what he said or did, and not by what he may think his state of mind to be." See Psycerrarruc Dictionary (3d ed. Hensey \& Campbell 1960).

12 Bankruptcy Act $\S 22$ (b), 52 Stat. 854 (1938), as amended, 11 U.S.C. $\S 45$ (b) (1958).

13 Bankruptcy Act $\$ 39$ (b), 60 Stat. 326 (1952), as amended, 11 U.S.C. $\S 67$ (b) (1958).

14 Referees shall not (1) act in cases in which they are directly or indirectly interested; or (2) purchase, directly or indirectly, any property of an estate in any proceeding under this act. Active full-time referees shall not exercise the profession or employment of counsel or attorney, or be engaged in the practice of law. Active part-time Ibid. referees ... shail not practice as counsel or attorney in any proceeding under this act. 
time, for the convenience of parties or for cause, transfer a case fron one referee to another." 15 The leading cases indicate that a district judge, in ruling on a motion for disqualification, will be reversed only for an abuse of his discretion. ${ }^{16}$ Sonve district judges take the position that when "cause" for disqualification exists they may directly decide the issues and need not transfer the proceeding to another referee. In jurisdictions such as New York or California the abundance of referees makes transfer to another referee a practical solution. On the other hand, in judicial districts where there is only one full or part time referee, the option of the district judge to hear the matter himself might well save time and money for the litigants and the government.

What constitutes sufficient "cause" for disqualification of a referee is not defined by section 22 (b), but current case law indicates that such "cause" may be analogous to the grounds for disqualification of a district judge. Undoubtedly, "cause" could be shown by remarks by the referee or other proof indicating blatant prejudice or passion.

Although a party may in fact be prejudiced because of a referee's overexposure to the matters arising in the normal course of the administration of a debtor or bankruptcy proceeding, apparently at present this alone is not grounds for disqualification. There are two potential legislative solutions to this dilemma. On one hand, the complaining claimant might be required to submit proof to the district judge that either through court or chamber contacts the referee has been substantially exposed to statements, evidence, or testimony that would bear upon the ultimate findings of fact in the creditor's proceeding. Perhaps less personal, and less enubarrassing to the regular appearing bankruptcy practitioner, would be an option by which the claimant, now subject to a cause of action by the estate for an affirmative judgment, could have the right arbitrarily to move for the disqualification of the referee handling the particular estate. Thereafter, he would be entitled to a hearing before the district judge or another referee. This alternative apparently has met with success in state court actions, including California. ${ }^{17}$

Avoidance of a multiplicity of actions, delays, and additional expense, the enjoyment of the usual beneficial results of a bankruptcy proceeding, and the protection available to a creditor througlı judicial disqualification certainly justify the continued recognition and enforcement of the sum-

15 Bankruptcy Act $\S 22$ (b), 52 Stat. 854 (1938), as amended, 11 U.S.C. $\S 45$ (b) (1958).

10 See In re J. P. Iinahan, Inc., 138 F.2d 651 (2d Cir. 1943); Union Trust Co. v. Townshend, 133 F.2d 501 (4th Cir. 1943); Anchor Grain Co. v. Smith, 297 Fed. 204 (5th Cir. 1924); In re Lozito, 43 F. Supp. 149 (E.D.N.Y. 1941); Bray v. Cobb, 91 Fed. 102 (E.D.N.C. 1898).

17 Cad. Code CIv. Proc. \$ 170.6. 
mary jurisdiction of the referee. To minimize the delay and uncertainty of appeals, this expanded jurisdiction should be expressly codified in the Bankruptcy Act. ${ }^{18}$ Constant litigation over the vexatious problems of jurisdiction serves no useful purpose. Furthermore, because of the nature of a bankruptcy proceeding and the protection needed by the claimant who has submitted to the bankruptcy court's jurisdiction, the act should be amended to spell out fair rules of judicial disqualification.

\footnotetext{
${ }^{18}$ See Nadler, supra note 3 , in which it is stated:

And so, as the trend gains momentum and cases on this question of summary jurisdiction are being decided, it is to be expected that here and there, now and then, a decision may be contra to the stream. And yet trends develop principles that eventually end up in legislative recognition of the organic law. Congress, it is therefore hoped, will soon enact a specific amendment, clarifying and recognizing that the bankruptcy courts bave summary jurisdiction over all aspects of a situation involving the expeditious administration of the bankruptcy estate! So inuch future confusion can so easily be avoided!
}

Id. at 42. Unfortunately legislative action has been painfully slow. H.R. 4855, 87th Cong., 2d Sess. (1962), a bill imtroduced at the recommendation of the Judicial Conference, would extend the suniniary jurisdiction of the referee to include actions arising under the Bankruptcy Act $\S 60,64$ Stat. 25 (1950), as amended, 11 U.S.C. $\$ 96$ (1958) (covering voidable preferences); Bankruptcy Act $\S 67,66$ Stat. 427 (1952), as amended, 11 U.S.C. $\S 107$ (1958) (covering hens and fraudulent transfers); Bankruptcy Act $\S 70$ (e), 66 Stat. 429 (1952), as amended, 11 U.S.C. $\S 110$ (e) (1952) (covering title to real property). According to the latest information available, nothing has happened to this bill since a hearing held on April 12, 1962. A resolution of the Judicial Conference, Res. No. 36 , involves the recognition of the bankruptcy court as a court of record, but no progress report is available at this time. 